\title{
Kadunud linna otsimas \\ Sõjajärgse Tartu palimpsest Bernard Kangro ja \\ Jaan Kaplinski romaanides
}

\author{
ENE-REET SOOVIK
}

Maastike tõlgendamine kihiliste ning palimpsestlikena on geograafias kontseptuaalse lähenemisena kinnistunud (Crang 1998: 22) ning ka humanitaarse suunaga linnauuringutele on inspiratsiooni pakkunud kas reaalsete (nt Huyssen 2003) või kirjanduslike linnamaastike (nt Plesske 2014) palimpsestlik loomus. On osutatud, et palimpsest on „tänapäevase linnaproosa põhimetafoor” (Plesske 2014: 304). Artiklis kasutatakse palimpsesti mõistet, vaatlemaks kirjanduslikke kujutusi linnast, mis on sõjas tugevasti kannatada saanud ning mille taastamine toimub kadunud linna loonud sõjaeelse ideoloogilise keskkonna eitamise tingimustes. Artiklis võrreldakse Bernard Kangro romaani „Tartu” (1962) lõpuosa ja Jaan Kaplinski teose „Seesama jõgi” (2007) Tartu-kujutusi ehk Teise maailmasõja purustustest taastuva ning nõukogude võimu tingimustes ümber kujuneva palimpsestliku linnaruumi taasloomisi kirjanduses.

„Tartu” lõpetab Kangro nn Tartu-tsükli esimese triloogia, mis keskendub sõjaeelsetel aastatel ja sõja ajal toimuvatele sündmustele. Erandiks on „Tartu” viimane osa, milles tsükli olulisimaid tegelasi Benno Maran teeb unenäolise külaskäigu autori kaasaegsesse Tartusse. Aastatel 1959-1962 romaani kallal töötanud Kangro kirjeldab linna, mida ta pole Rootsis veedetud aastate vältel uuesti külastanud. Kaplinski heidab omakorda tagasipilgu Benno visiidiga samal ajal Tartus õppiva tudengist peategelase suhetele naissooga ning Õpetajaks nimetatud vaimse mentoriga, kelle kuju tugineb Kangro kaasarbujale Uku Masingule. Aastatel 1958-1964 Tartu ülikoolis õppinud Kaplinski on saanud toonase linnakeskkonna kujutamisel toetuda isiklikele kogemustele. Ka Thomas Salumets rõhutab oma põhjalikus Kaplinski-uurimuses „Sellesama jõe” autobiograafilisust (2016: 62, 71, 98-99, 118-119, 124, 126).

Nii „Tartu” kui ka „Seesama jõgi” on seega kirjutatud distantsilt, ent Kangrot lahutab kirjeldatavast ruumiline, Kaplinskit ajaline vahemaa. Mõlemas teoses esitletakse 1960. aastate alguse Tartut, mille rekonstrueerimisprotsess muutunud ühiskonnakorra tingimustes on juba mõnda aega toimunud. Linnakogemust vahendatakse humanitaarharitlase vaatevinklist, kellel on ühisosa autoriga, ning järgitakse tema liikumist linnas, mille käigus sekkuvad vahetusse kogemusse ajalooliste kihistustega ühendusi loovad mälupidemed. Teoste mitmekihiliste linnamaastike käsitlemist toetavad peale palimpsesti ja mälu materiaalsuse mõistete ka Michel de Certeau tähelepanekud linnas kõndimisest kui lausumise ruumist. 


\section{Linnapalimpsest ja mälu}

Üks praeguseni viljakamaid palimpsestikäsitlusi pärineb Thomas de Quinceylt (1785-1859). Teda köitis palimpsestile omane esialgse mahakustutuse luhtumine ja peidus püsinud kirja taasilmumine, mida ta seostas inimaju meeldejätmisvõimega. Sarah Dillon (2005: 246) toob välja de Quincey argumentidest tuletatava surma ja kaduvuse eitamise, mis toimub objektide ja isikute pideva elustamisena neid meenutavas ajus, Aleida Assmann (1999: 154-155) aga tuletab de Quinceyst lähtuvalt palimpsesti edasise hargnemise ja kihistumise idee.

Konkreetselt linna palimpsestlikku olemust on käsitlenud Michel de Certeau, kes on otsesõnu väitnud, et koht ongi palimpsest (Certeau 2005: 273). Certeau ruumipraktikate mõiste hõlmab nii meeles püsivat kui ka unustatut ning rõhutab mälestuste rolli, millesse kuulub „avaliku ja peidetu aktiveerimine, see, mida avalikult mälestatakse, ja see, mida inimesed on sunnitud unustama" (Lagerkvist 2011: 36), näidates seega üksikisiku ja linna kollektiivse mälu vastastiktoimet. William Uricchio (2012) toonitab Certeau rõhuasetust praktikale ja performatiivsusele, mis kogemuse kaudu annab kohale tähenduse. „Aja materiaalsete konstellatsioonidena annavad linnad tunnistust oma minevikust ja oma teisenemise lõputust protsessist, ümberkirjutamisest ja unarusse jätust" (Uricchio 2012: 47). Eriti tuleb see ilmsiks selliste ruumipraktikate käigus nagu jalutamine. Jalutaja assotsiatsioonid on isiklikud ja ainulaadsed, uidaku ta siis tegelikus või meenutatavas keskkonnas. Nagu kirjutab Certeau (2005: 161), tekitab kõndimine „ruumikorralduses varje ja kahemõttelisust, viib sinna vargsi sisse hulganisti omaenda osutusi ja tsitaate". Teatud mälupidemed on aga peamiselt seotud ühise ajalooga ning Uricchio (2012: 48) osutab, et näiteks avalikus ruumis paiknevad skulptuurid on meenutuste linna esmaste avalike mälupäästikute seas.

Monumentaalskulptuuride mälufunktsiooni on käsitlenud Marek Tamm ja Saale Halla, kes möönavad, et avaliku ruumi ümberkorraldamine, näiteks vanade mälestusmärkide likvideerimine ja uute püstitamine, teede ja väljakute rajamine ning ümberkujundamine, avaldab tõenäoliselt otsest mõju kollektiivsele identiteedile (Tamm, Halla 2008: 21-22). Kõikidest režiimidest jääb alles monumente, mis näitlikustavad arusaamu sellest, mida tuleks minevikust esile tõsta, ja kui seesugused monumendid muutuvad mälukollektiivi jaoks tähenduslikuks, ei loobuta neist kergesti (Tamm, Halla 2008: 47). Poliitilise režiimi vahetudes käivituvad nii kustutamiskui ka ülekirjutamismehhanismid, mis suure tõenäosusega puudutavad avalikus ruumis paiknevaid mälestusmärke ja mõjutavad seega nii isiklikke kui ka kollektiivseid mälupidemeid.

Mälupidemete teisenemine ei ole aga seotud üksnes mälestusmärkidega. Kaduda võivad tunduvalt suuremad rajatised ning ehitised, olgu siis lammutamise teel või seetõttu, et nende funktsiooni muudetakse või nad hävivad sõjas strateegilise sihtmärgina, nagu sillad, või kollateraalse kahjuna, nagu paljud tsiviilhooned. Kirjandusteadlane Valentine Cunningham toob välja, et maatasa pommitatud hooneteta linnad koosnevad üksnes tänavajoontest, oma vana identiteedi „sõrestikmustritest” (2002: 110) ja puuduvate mälupidemete tõttu võib sellise linna äratundmine ning 
selles orienteerumine olla ootamatult keeruline (2002: 120). Ka hävinud linnajagude taastamise printsiibid võivad osutuda äärmiselt komplitseerituks (Cunningham 2002: 127). Andreas Huyssen (2003) on käsitlenud Teises maailmasõjas tekkinud tühja ruumi keset Berliini, mida hoidis alal Berliini müüri rajamine 1961. aastal. Ka pärast müüri lammutamist 1989. aastal jäid seda ümbritsenud ruumis kõnekalt esile kustutamise, ülekirjutamise ning säilitamise palimpsestlikud jooned. Kõneldes Berliini kesklinnas asuvast arhitektuurilisest tühermaast, mida ta kirjeldab kui „sõjast, hävingust ning järgnenud ajalooliste sündmuste jadast tulenevat avatud linnaruumi” (Huyssen 2003: 69), tõstab Huyssen esile Berliini juudi muuseumi arhitekti Daniel Liebeskindi ettepaneku, et selle võikski jätta metsikuks, loomaks kuvandit tühjusest, mida ei ole hõlbus kustutada (Huyssen 2003: 65).

Ehitatud keskkonna teisenemine on tihedasti seotud nimetamise ja ümbernimetamisega. Mälestusmärke käsitledes on Sanford Levinson (1998: 19) täheldanud: „Nimed on tähtsad ning suutlikkuses panna konkreetseid nimesid peitub oluline võim, mis tuleb ilmsiks, nagu oluline võim tihti, näiliselt kõige labasemal moel." Certeau (2005: 165) kõneleb pärisnimede väest: „Pärisnimed uuristavad ruumidesse, mida võõras mõistus jõhkralt läbi valgustab, varjatud ja tuttavlike tähenduste pelgupaiku." Semiootikute Juri Lotmani ja Boriss Uspenski (1999) jaoks tähendab ümbernimetamine varasema objekti hävitamist ja selle asendamist uuega, mis vastab paremini ümbernimetaja vajadustele. Tartugi on ajaloo vältel kandnud erinevaid nimesid, olgu siis Dorpat, Derpt või Jurjev, ja selle ehitatud keskkond on läbi teinud mitmeid kustutamis- ja ülesehitustsükleid, millele järgnevalt heidetakse põgus pilk.

\section{Tartu palimpsesti kujunemine}

Tõik, et Tartu on Baltimaade vanim linn, ei peegeldu ehitatud linnakeskkonnas teadupärast kuigivõrd. 1827. aastal kõrvutas Karlova mõisa omanik kirjanik Faddei Bulgarin linna saatust Paabeli ja Jeruusalemma piibelliku hävitamisega:

Kuigi poeesia vaikib Tartu õnnetust saatusest ja see linn pole maailmas nii kuulus nagu Assüüria ja Juudamaa pealinnad, on Tartu elanike õnnetused olnud sama suured. Seda õnnetut linna on laastanud nälg, taudid, sõda, tuli ja tagakiusamised usu pärast. Selle linna elanikke on tapetud ja võõrsile veetud. Tartut on neliteist korda piiratud ja üksteist korda rüüstatud ning laastatud. (Bulgarin 2019: 340-341)

Ent luule osas Bulgarin eksis: kui Peeter I tegi Põhjasõjas linna maatasa, andis see Käsu Hansule inspiratsiooni, panemaks aluse eestlaste kirjutatud eestikeelsele luulele. Ahastuse väljendamiseks oli igati alust, sest 1710. aastal oli Tartus vaid neli säilinud hoonet ning 21 linnakodanikku, umbes 800 inimest oli kaks aastat varem Venemaale küüditatud (Salupere 2011: 22-23). Seega sündis eesti luule tühjas ruumis, mis jäi maha nii linna kui ka selle praktiseerijate sihipärasest pildilt kustutamisest.

XVIII sajandil leidis vast ülesehitatud linnas aset kolm suuremat tulekahjut ning 1775. aastal põles maatasa kaks kolmandikku linnamüüri sisse jäänud hoonetest 
koos kahe üle Emajõe viiva sillaga, mis võimaldas tulel teiselegi kaldale levida - tegu oli kõige hävitavama rahuaegse põlenguga Eestis (Laur 2005: 61). Nii annabki kesklinnas tooni seejärel taastatud ala klassitsistlik arhitektuur. Linna taastamisprintsiibid järgisid Tsaari-Venemaal Katariina II ajal levima hakanud euroopalikku arhitektuurimõtet, mis saavutas haripunkti Aleksander I päevil (Tohvri 2004). XIX sajandi teine pool tõi linnapilti historitsismi ja juugendi (Siilivask 2006), iseseisvusaastatel lisandus neile funktsionalism, mida eriti silmatorkavalt edendas XX sajandi moodsa arhitektuuri süsteemne alusepanija Tartus, Karlsruhes koolitatud linnaarhitekt Arnold Matteus (Kivi 2017: 125), kes tegutses linnaarhitektina ka Teise maailmasõja ajal ja järel. Sõda viis Tartu linnapildist mitu olulist maamärki: Kivisilla, mille Katariina II oli lasknud ehitada pärast 1775. aasta tulekahjut esimese kivist sillana Balti provintsides, ning 1923. aastal avatud betoonist Vabadussilla, esimese omasuguse Eesti Vabariigis. 1944. aasta augustis, kui rinne taas üle linna liikus, langesid varemetesse Vanemuise teater ning Jaani ja Pauluse kirik. Sõjas kadus üle 50\% eluruumidest ning 46\% tööstusettevõtetest (Siilivask 1960: 9-10), hävis 2288 hoonet (Matteus, Seero 1960: 24).

Geograaf Ann Marksoo on Tartu linna sõjajärgse taastamise jaganud kolme etappi. Aastatel 1945-1950 lammutati varemeid ja taastati pooleldi hävinud hooneid, purunenud kvartalid Emajõe kallastel kujundati parkideks ja platsideks, mida käsitati tulevasteks arendusteks reserveeritud ruumina (Marksoo 2005: 148). Linnaarhitekt Matteus kavandas hoonete asemel haljasalasid, kuhu istutati 8000 puud ja 28000 põõsast (Matteus, Seero 1960: 24) - see oli teadlik tegutsemissuund, et vältida kesklinna täitmist nõukogulike ehitistega (Pajur 2005: 91). Eesmärgiks ei olnud küll hävinu mälestamine tühjuse kaudu, ent keeldumine sisustamast linnaruumi nõukoguliku standardarhitektuuriga meenutab siiski Liebeskindi ülalmainitud ettepanekut Berliini ajaloomälu hoidmiseks.

Järgmisel perioodil, aastatel 1951-1964, mille raamesse jäävad siin vaadeldavate tekstide sündmused, hakati peale ühiskondlike hoonete ehitama ka esimesi neljaviiekorruselisi kortermaju (Marksoo 2005: 148). Sellest perioodist pärinevad nn hruštšovkad, mida püstitati kõikjal Nõukogude Liidus. Alates 1959. aastast kasutati enamiku Tartu elamute ehitamiseks standardprojekte (Matteus, Seero 1960: 26). Matteus, kel oli õnnestunud sulandada stalinistlikke hooneid Raekoja platsi klassitsistlikku hoonekompleksi, üritas suunata tuimailmelised uuselamud südalinnast eemale, näiteks Tiigi tänava põlengualale.

Aastatel 1965-1990, Nõukogude Eesti linnaehituse lõpp-perioodil, rõhutati linnaosade funktsionaalset eristamist ning püstitati kõrghoonetest koosnevaid magalarajoone (Marksoo 2005: 149). Tartu laienemist piiras nõukogude ajal linna ümbritsevate ühismajandite maavajadus, mille kohta Marksoo (2005: 148) täpsustab, et 1950.-1960. aastatel olid need veel majanduslikult nõrgad ning pigem arvestasid linna soovidega. Tsiviilehituse laienemist takistas aga linna kirdepiirile endisesse Raadi mõisa rajatud „üks kaheksast suurimast NLi Euroopa-osa sõjaväelennuväljast, mille kinnine territoorium algas 1 km kauguselt Tartu Raekojast” (Preem 1996). Selliste printsiipide ja piirangute järgi vormuvas keskkonnas leiavadki aset Kangro ja Kaplinski teostes kujutatud kõndimised. 


\section{Ülekirjutuste trotsimine Kangro "Tartus"}

„Tartu” algab hävinguga - tegelaste hukkumisega Berliini pommitamise käigus. Ometi teeb nõnda surnud sõjapõgenik Benno Maran teose lõpus külaskäigu oma nooruslinna Tartusse. Romaani on pikitud kursiivkirjas kommentaare minajutustajalt, kes dequincey'likult usub maetud mälestuste elustamise võimalikkusse nagu tema alter ego Bennogi (Hollo 2016: 84-85). Enne Benno Tartus käiguni jõudmist selgitab jutustaja, kooskõlas hilisema humanistliku geograafia hoiakutega (vt Jauhiainen 2005: 109-130):

Tartu ja selle elu oli ikkagi selgesti piiriteldav mõiste, see oli - võiks väita tagantjärele maailmatunnetuse vorm. Mõiste „Tartu” moodustasid inimesed ja nende elu ning mõttemaailm, linn oma geograafilises ja ajaloolises tegelikkuses ja lõpuks meie ise - tunnetav mina. See oli seesmiselt lóhestatud ja lahkuhoidev, väliselt ometi kompaktne üksus.

See omaette maailm hakkas lagunema koos nende mullistustega, mis tabasid Euroopat kümnendite vahetusel. Sõjatules hävis mitte ainult valdav osa Tartu linnast, suur hulk ta inimestest, vaid ka selle vaimne olemus. Kadus mõiste „kolmekümnendate aastate Tartu", kadusid koordinaadid meie kaasaegsete arengu hüplevale, otsekui palavikus tuksuvale kõverale. (Kangro 1996: 193)

Ent pisut hiljem nendib kirjanik: „Hoolimata hävingust, mis tabas vana Tartut varsti peale seda, kui me jutustus katkes, ei põlenud kõik selles tules tuhaks. Palju jäi ka alles, kuigi muutunud kujul. Ja jälle pöördub meile vastu Tartu ühe uue murdumisnurga all." (Kangro 1996: 194)

Muutunud allesjäänuga kohtuma saabunud Benno paneb ümbritsevas tähele nii looduselemente (see on Kangro linnakirjeldustele iseloomulik, vt Soovik 2019: 75-76), ehitisi kui ka inimpraktikaid. Kõige tugevamalt reageerib ta meenuvale: pidevalt kerkib ta vaimusilma ette mälestuste Tartu, mis seab end hetkel domineeriva kultuuriteksti kõrvale, kuigi viimane peaks marginaalseid tendentse varjama, nagu on osutanud Plesske (2014: 304). Benno avastab, et „[e]hkki palju on kadunud ning muutunud, kohtad veel igal sammul ja ootamatus ühenduses endist ning tuttavat" (Kangro 1996: 195). Ilmneb surma ja kaduvuse ületamise võime, mida de Quincey omistas palimpsestile, kuid vahetevahel lõikab Benno teadvusse arusaam, et haljas rohi ning kevadised hiirekõrvus puud asendavad hooneid, mida ta vanast ajast mäletab: „Saame vaevalt Riia mäelt pilgu alla jõele heita. See vaade on mulle täiesti uus. Siinpool jõge pole enam maju, vaid haljasalad puude ja põõsastega. Kuidagi valus on seda vaadata." (Kangro 1996: 209)

Emajõe voolamine esindab küll aja igavest voogu, kuid „[---] vanad sillad on kadunud ja nende asemel on uued. Kuigi ka vastsetest võid üle kõndida, otsid ometi vanu." (Kangro 1996: 195) Raekoja platsi stalinistlik-klassitsistlik mimikri toimib ta nostalgilise pilgu ees edukalt, aga väljaku taust on teisenenud: „,---] kui selg endise Kivisilla ja praeguse uue jalakäijate silla poole pöörata, on vaade peaaegu nagu vanasti. Suurturu, praeguse Nõukogude väljaku ääres on endiselt majad, raekoda vaatab fassaadiga vastu. Kuid nüüd paistab kahelt poolt hoonet Toomemäe nõlvak." (Kangro 1996: 196) 
Säilinu ning muutunu vaheldumine toob kaasa vastandlikke emotsionaalseid reaktsioone: „Siis hakkavad paistma ülikooli peahoone valged sambad. Oo, kuidas need on endised! Kuid see seal! Peab see tömp moodustis olema kunagine Jaani kiriku torn?” (Kangro 1996: 199) Murenenud mälupidemete tõttu pole Benno enam kindel, millisesse ajakihti vaadeldavad, ebamääraselt kohatuna tunduvad hooned õigupoolest kuuluvad (Kangro 1996: 206). Teisalt aga tunnustab ta Matteuse haljastusprojekti teisendavat väge, seda, kuidas rohelus tuleb toime nii minevikulise hävingu kui ka olevikulise okupatsiooniga: „Rohi aga iiletab rõõmsasti parkides, aedades ja haljasaladel, mis on asutatud kunagiste varemete asemele” (Kangro 1996: 195); „Laiguti on linnas tühje kohti, haljasalasid, kus puud juba üsna suured, ja kui ei mäletaks, et olid majad, ei teaks üldse, et miski puudub" (Kangro 1996: 206).

Bennot rõõmustavad tuttavad vaatepildid, nagu Toomemäe teed, Baeri ausammas ja Tähetorn. Isegi sammude kaja Inglisillal ning vihmavee uhutud vaod mäenõlva kruusas näivad tuttavatena ja kui ta läheneb oma kunagisele üürikorterile Karlova linnajaos, tundub see kojutulekuna. Ühtlasi heiastuvad talle hävinud hooned, olgu siis ajalooline Pallas või fiktsionaalne Taaratütarde konvent. Olnu ja olev põimuvad - Certeau (2005: 170) sõnu kasutades: „Hämmastaval kombel kujutavad need läbielatud kohad puuduoleva kohalolu. See, mis end näitab, tähistab seda, mida enam ei ole [---]." Linna mineviku- ja olevikukihi üheaegne teadvustamine tekitab Bennos viimaks irreaalse ajaülese meeleseisundi, milles ta tunneb, nagu oleks ta mitu inimest eri aegadel, kes end kohati korraga ilmutavad:

Ma ei olnud nagu mitte kuski, aga samal ajal just kui igal pool. Ma tunnetasin selgesti aja möödumist ja käesolevat silmapilku, kuid oma vaimusilma ees nägin nagu ühel salajasel ekraanil ennast ühel hoopis teisel ajal samu tänavaid mööda ringlemas. Ja mis kõige imelikum - ma ei olnud mitte ainult mina ise üksi, vaid mitu inimest üksteise järel, jah, vahel isegi nagu samal ajal. Ja linn, mille tänavail hulkusin, polnud mitte ainult minu noorusaja Tartu, terve ning puutumatu, vaid ka praegune hävitatud, kulunud, ümberehitatud ning muutunud. (Kangro 1996: 216)

Selline tõeliselt palimpsestlik linnakogemus aegade kuhjatisena, mis võib ka uuesti laiali pudeneda (Certeau 2005: 170), või aja materiaalse konstellatsioonina (Uricchio 2012: 47) võtab kokku läbikumavate linnakihistuste segadusse viiva samaaegsuse.

„Tartu” lõpuosa lehekülgedel on seega tegu pea katkestamatuna meenuva nostalgilise mineviku ja olevikus puuduolevate endiste ehitiste tajumisega, uue ilminguid samavõrra ei märgata. Erandiks osutub Lenini kuju hoone ees, mida Benno määratleb ikka veel kaitseliidu majana, kuigi tema noor saatja Hele-Mall kõneleb sellest kui Põllumajanduse Akadeemiast. Monument on otsene märk uue võimu vallutatud linnaruumist ning Tartu ajaloo uue ametliku kirjutuse mälupide. Naljatamisi kutsub Benno aga kuju saksaaegse komissari järgi Kurt Meeneniks, põimides seega kaht totalitaarset režiimi ja nende ajalookujutusi ning samal ajal end mõlemast distantseerides. Ühtlasi ilmneb, et Benno ja Hele-Mall liiguvad linnas erinevaid mentaalseid kaarte kasutades, nad nimetavad objekte erinevalt: Suurturust on saanud Nõukogude väljak, Wernerist kohvik Tartu, söögisaali Koit asendab Võit ning 
Ateeni Volga. Hele-Mallele on uus nimekeskkond omane, ta võib rääkida intritest Pälsoni ja Kingissepa tänaval ning Marxi majast ja selle ideoloogilisest sisust, kuid Benno mõtestab Tartut järjepanu iseseisva Eesti toponüümika kaudu, nähes näiteks Lätte tänava asemel hoopis Lossi tänava algust ja seistes seega vastu oma ruumi semiootilisele kaotamisele Lotmani ja Uspenski mõttes. Pärisnimed „tekitavad [---] kohas tolle erosiooni” (Certeau 2005: 167) ja linnapalimpsesti pealispinna alt hakkab paistma möödanikukiht. Benno kohanimede reaalsus rajab sarnaselt Certeau pärisnimedega "funktsionalistlikus ja ajaloolises liiklemise korras vargsi uusi marsruute” (Certeau 2005: 166), kuigi nõukogude tänavakorda katkestavad Benno „uued” marsruudid on hoopis varasemad. Certeau (2005: 167) leiab, et kohti sõnadega rüütavad pärisnimed muudavad need elamiskõlblikuks või usutavaks ning meenutavad või kutsuvad linnas välja vaime ehk kadunuks peetud surnuid. Tartut omaaegsete nimedega nimetav Benno loobki nii endale kongeniaalse keskkonna, milles temasugusel võib-olla-vaimul on võimalik kõndijaks kehastunult ilmuda.

Mis puutub vanade majade uutesse funktsioonidesse või uutesse hoonetesse, siis need esinevad Kangro linnas vaid ebamääraselt, näiteks suurte valendavate majaplokkidena, mis on ",arvatavasti uued, sest nad on kuidagi nagu endisest pildist väljas" (Kangro 1996: 206). Uus esineb Hele-Malle selgitustes, näiteks Tiigi tänava vast hoonestatud piirkonda kommenteerides: „Siit silmakliiniku juurest läks otsetee Tiigi intrisse. Siit olen nii palju kordi käinud. Nüüd ehitatakse majad ette. Ja Tiigist instituutide hoonesse. Siin oli päris tühi ja paljas. Näed, nüüd on Maarja kiriku ja kunstikooli ümbruseski terve kobar uusi maju. Maarja kirik on nüüd võimla..." (Kangro 1996: 209) Omal ajal teatriga seotud Benno soovib heita pilgu ka Vanemuise varemetele, kuid Hele-Mall suunab ta teisele teele ja teatri asukoht jääb nägemata - seal olekski paistnud ainult ehitusplats, sest varemed õhiti 1957. aasta 19. mail ning 1960. aastal pandi nurgakivi uuele hoonele (Vanemuine 2017).

Kõige uue vältimise põhjus võibki olla asjaolu, et autoril endal puudus sellega vahetu kokkupuude. Seda lünka kirjanik ka teadvustab: mefistolik Justus Pernambuk, kes juhib Benno päeva lõpul igavikujõeks Styxiks muunduval Emajõel ootavasse paati, hurjutab toda otsesõnu, et ta uue Tartu vastu huvi ei tundnud. Benno aga vastab teatri kujundeid kasutades, et uued rajatised on vaid dekoratsioonid: „Neist teab igaüks, et need on maalitud, ajutised, mida iga uue vaatuse eel vahetatakse. Oluline on sisu - inimene." (Kangro 1996: 265) Tõepoolest, inimesed ja nende argitegevused, millest Benno osa saab - loengus käimine, Werneris istumine, restoranis inimestega kohtumine, endisaegse mööbliga sisustatud Karlova tudengitoas kirjanduse üle vestlemine, samuti jalutamised, eriti Toomemäel ja jõe ääres - defineerivad linna, mida ikka veel etendatakse püsivate mustrite järgi ning mis on seega elus ja jagab seda elu Bennogagi, olgugi too surnud ja Berliini rusude alla maetud. See, mida Benno tunnistab ja tähtsaks peab, illustreerib kujukalt Certeau esile toodud argipraktikate vastupanuvõimet domineeriva korra totaliseeriva linnakäsitluse suhtes.

Kahekordistatud aegade vahel viibiv Benno tunneb küll ise, et ta on „nagu kodukäija, nagu vana hall vaim, kes ei tea, kuhu ta kuulub - uude või vanasse, kas ta ise muidu üldse eksisteerib kui mõne teise teadvuses ja kujutluses" (Kangro 1996: 213). Ent temasuguste vaimude olemasolu muudab nõukogudeaegsete tegelaste (seega ka 
Kaplinski peategelase) jaoks päriselt olevaks kogu linna kui palimpsestliku paiga, sest, nagu kirjutab Certeau (2005: 170): „Tõeliselt on olemas ainult need kohad, kus kummitab terve hulk vaime, kes seal vaikuses redutavad ja keda võib „välja kutsuda” või „kutsumata jätta”' Küllap pakkus kustutamise ja kao palimpsestliku trotsimise ning argipraktikate varjatud vastalisuse esiletoomine lootust ja lohtu ka Kangro pagulaslugejatele, sellest hoolimata, et romaan esitles midagi, mis ei tarvitsenud olla õige Tartu, vaid kujutletud, enese loodud linn, oma fantaasia pealinn, nagu Bennogi viimaks kahtlustama hakkab (Kangro 1996: 264-265). Igatahes pälvis „Tartu” 1963. aastal Henrik Visnapuu auhinna parima paguluses ilmunud eesti kirjandusteosena.

\section{Vastuseis mälu muutmisele Kaplinski romaanis "Seesama jõgi"}

Nagu Kangro, nii iseloomustab ka Kaplinski Tartut teatri kujundit kasutades, ent seostab linnaruumi teatraalset elementi inimpraktikate muutlikkusega: „Ülikool ja terve juulikuine Tartu hakkas meenutama teatrit pärast etendust, kui lumm on korraga otsa saanud, publik liigub riidehoiu poole ja näitlejad võtavad näolt grimmi” (Kaplinski 2007: 86). Nagu andis mõista de Quincey palimpsestikäsitlus, ei tähenda näidendi lõpp siiski selle unustamist ega matused inimese meenutamise lakkamist. „Seesama jõgi” algab Õpetaja matusega, mis Uku Masingu ärasaatmist silmas pidades pidi aset leidma 30. aprillil 1985. Linnaruumi silmanähtav, eri ajastuid koondav kihilisus tuleb palimpsestlikult esile juba sissejuhatavas osas, kus matuserong liigub mööda tänavat, mida asfalt katab üksnes keskelt, äärtes aga paljastub vana munakivisillutis. Mineviku kustutamise, unarusse jätmise ja taaskasutamise segu avaldub, kui sark sängitatakse Raadil vanale saksa surnuaiale, „mis pärast sõda oli metsistunud, kus hauakivid, ristid ja väiksed kabelid olid lagunenud ja rüüstatud. Osa haudu oli veel alles, osa oli ülikooli rahvas jälle korda teinud, mõnele lõhutu asemele isegi uue kivi seadnud." (Kaplinski 2007: 6-7) Edasised linnapildid aga kuuluvad peategelase ülikooliaastatesse pea veerandsada aastat varem.

Nagu Kaplinski luuleski, on „Sellessamas jões” enim tähelepanu pööratud Tartu looduslikule mõõtmele (vt Velsker, Soovik 2017: 102-106). Peategelast köidavad Toomemägi, sealne park ja vaade üle linna ning Emajõgi, jõeärne rohelus ja selle jätk linnapiiri taha jääva poolmetsiku alana. Retked viivad teda ka linnast välja maastikku kogema, samal ajal ei kirjeldata lähemalt ega meeletajusid kaasavalt kesklinnas asuvaid ülikoolihooneid, kohvikut ja raamatukogu ning ülerahvastatud korterit, kus ta pere on elanud pärast vanaisa linnataguse maja konfiskeerimist sakslaste poolt ja asenduskorteri hävimist pommirünnakus 1944. aastal. Linnakirjeldustes pöörab Kaplinski ehitistele vähem tähelepanu kui Kangro ning ega linn reegleid kehtestava ehitatud keskkonnana ta tegelasele eriti meeldigi, pigem piirab ja ahistab teda. Peategelane läbib ilmselt üsna tihti Tiigi tänava ehituspiirkonda, kuid linna rajatavatest uutest hoonetest tuleb tal ülevaateid anda vaid siis, kui ta külastab maal elavaid sugulasi (Kaplinski 2007: 149). Traagiliselt rebenenud linnamaastik, mille keskel ta on üles kasvanud, jääb argikäikude vaikivaks taustaks. 
Erinevalt Bennost ei ole Kaplinski tegelane kogenud sõjaeelset Tartut, kuid linnas paelub teda just minevikumõõde, nostalgia kadunud nõukogude-eelse aja järele, mida Epp Annus (2019: 259) on nimetanud nõukogudeaegse „,argirahvusluse üheks nurgakiviks". Kadunud linn ei ilmuta end mitte avalikus ruumis, vaid kodudes, mis on sõja üle elanud ning aitavad säilitada järjepidevust fragmentaarselt ja vihjamisi toimiva minevikuga. Kui avalikust ruumist on püütud välja juurida seal kummitavad lood ja legendid (mida kehastab Kangro Benno), siis „see tähendab, et miski pole tähendusrikas, et miski ei avane mälestuses ega muinasloos, miski ei kanna teisesuse märki. Usutavaks jääb ainult oma kodukoobas, kus veel mõnda aega säilivad legendide urbed, varjude praod." (Certeau 2005: 168)

Nii keskendub Kaplinski tegelane esimesel külaskäigul Õpetaja koju palimpsestlikule nimesildile, mille kriidikirja kustutamisest alles jäänud sõna Adam (Kaplinski 2007: 12) võib meenutada kogu inimkonna, kõigi Aadamast põlvnenute ajaloolist kustutamist ja ülekirjutamist. Korteriukse kreemikasvalge värv, olgu see siis algupärane või pleekinud, võib olla veel eestiaegne ning knopkajäljed sellel meenutavad sedeleid, mille sõnumid pole vaatlejale enam kättesaadavad, ent mis tekitavad uudishimu kadunud sõnade sisu vastu. Selliseid hooneid kogeb peategelane nõukogude-eelsete ajakapslitena, milles on säilinud midagi olemuslikku varasematest perioodidest, eriti nende lõhnades: „Ta jõudis veel mõelda, et trepikojas oli midagi kummaliselt eestiaegset, isegi lõhn. Sellel majal oli oma isiklik lõhn, ta oli jäänud iseendaks, hoidnud nõukogude aja kiuste alles natuke tõelisemat iseennast."1 (Kaplinski 2007: 12) Hilisemal külaskäigul kogemus kordub: „Nendes ja terves toa õhkkonnas oli midagi, mis selgelt kuulus teise aega, teise maailma. Selles teises maailmas oli midagi ühekorraga kodust ja võorristavat. See meenutas natuke ta oma kodu: vanaisa ja vanaema eestiaegseid sõpru-sõbrannasid oma olemisega, oma juttudega." (Kaplinski 2007: 295) Vestetud lood loovad olulise osa väärtustatud kohtadest, kõrvutuvad Certeau (2005: 170) kinnitusega: „Kohad on killustunud ja kokku pakitud lood, nad on möödanikud, mille teised on näpanud endale lugemiseks, nad on aegade kuhjatised, mis võivad küll uuesti laiali pudeneda, kuid pigem siiski säilivad otsekui ootel jutustustena, jäädes ise piltmõistatusteks [---].'

Võrreldav möödanikutunne tekib peategelasel ka korteris, mida üürib talle huvi pakkuv tütarlaps Ester. Neiu ise peab oma üürituba vanamoeliseks ja kodanlikuks, noormees aga tunneb seal taas teretulnud ühendust minevikuga: „See eriline agulivaikus, milles oli otsekui alles midagi vana, midagi eesti- või isegi tsaariaegset. Pitslinad, kummipuu, vana mööbli ja vana maja lõhn, mis samuti pärit teisest ajast.” (Kaplinski 2007: 300) Üleajalist, kuigi argisemat sarnasust möödanikuga tunnetas külastatud üliõpilastoas Kangro Bennogi, kes leidis: „Üldiselt tuletab see omaaegseid tudengitubasid meelde, ainult kulunum ning rühkunum. Vahest ongi ta mõni säärane, mis vanastigi sama otstarvet on täitnud, sama kragiseva diivaniga, pruuni poleeritud kummutiga, mille ühe jala all värvimata puuplokk, nikerdatud jalgadega lauaga, raamaturiiuliga, mis nagu ausõna peal püsti seisab." (Kangro 1996: 210) Palimpsestikihid hakkavad sellises ruumis aga omakorda hargnema, nagu

\footnotetext{
${ }^{1}$ Sõjaeelsest ajast säilinud haritlaskodude muljet avaldavat atmosfääri meenutatakse elavalt ka nõukogudeaegsetes omaeluloolistes tekstides (Annus 2019: 272).
} 
osutas de Quincey põhjal Assmann, ning iseseisvusaja seest tulevad nähtavale jäänukid veel varasemast. Nii täheldab „Sellesama jõe” peategelane Õpetaja abikaasaga kohtudes: „Oli temagi, nagu maja, kus ta elas, hoidnud alles midagi kolmekümnendatest aastatest pärinevat, eestiaegset. Selles eestiaegses pidi aga olema ka midagi saksalikku, dorpatlikku." (Kaplinski 2007: 12)

Inimeste eluasemetes valitseb seega certeau'lik mitmesuguste puuduvate minevike kohalolu. Linna mineviku teistsugusust rõhutab Kaplinski kohanimega, mis toob esile Certeau osutatud nimega seonduva erosiooni, koha ametlikku tähendusse mittekoha uuristamise. Minevikukihid, millega noormees arvab end meeletajude kaudu ühendusse astuvat, põimuvad tema teadvuses nostalgiliseks "mittepraeguks”, lugude ja legendide kummituslikuks ilmaks, mida ta ise kogenud ei ole, kuid millesse ta sooviks oma ebatäiuslikust keskkonnast pageda:

Pääseks kasvõi mõnda eestiaegsesse fotosse, kolmekümnendate aastate Tartusse, millest üks või teine tuttav oli rääkinud. Parikaste Tartu-fotodel oli samasugust lumma kui Düreri piltidel, neist hõngas rahu, nad rääkisid peaaegu kuuldavalt teistsugusest ajast, teistsugusest elutempost. (Kaplinski 2007: 259)

Just legendide ja jalutamise kaudu on võimalik ruumi teisesusse liikuda ja seda läbi elada (Certeau 2005: 168). Sunnitud kolimistest märgitud lapsepõlv, millesse kuulusid sõjapagu maal ning varemed, mille vahel võis peitust mängida ja tules moondunud esemeid avastada, polnud kuigi rahulik, ent pakub ruumikogemusele algpunkti, millest lähtudes ei tähenda ülesehitustööd kadunud linna taastamist, vaid üksnes keskkonna teisenemist.

Teisenemine kui protsess tuleb enim ilmsiks seoses sildadega, mis Certeau (2005: 191) jaoks on vastalised, koha seadusele allumatud objektid, mis rikuvad piire ning viitavad segadusse ajavale mujalolekule, olles seega alternatiivsete tähendustaskute otsijaile igati kohased huviobjektid. Kaplinski tegelane märkab nimelt kalastajat Vabadussilla varemete juures (tema teadvuses püsivad nii Vabadussilla kui ka Werneri nimed) ja seega ka varemeid endid (Kaplinski 2007: 289). Ta pole küll näinud õhitud betoonsilda, varemed aga tuletavad talle meelde selle sõjaaegset järelkäijat: „Silda ta mäletas, nagu see oli olnud sõja ajal, kui sakslased olid selle taastanud” (Kaplinski 2007: 289). Sild tekitab ka assotsiatsioone meenuvate võimsate üleujutustega, mis seob seda omakorda teistegi, samuti vaid mälestustes eksisteerivate Emajõe sildadega: „[---] jää vedas minema pontoonsilla jupid, ähvardas lammutada puusilla turuhoone juures, ujutas üle Supilinna madalad tänavad ning aiad, nii et majade vahel sõideti paatidega [---]" (Kaplinski 2007: 265-266). Vaimusilmas ilmuv puusild lammutati 1957. aastal, sest eelmisel aastal oli valminud praegugi käibel olev Võidu sild, mis Kangro (1996: 213) jaoks oli „uus” sild ning mille elav liiklus tundus Bennole tuttavlikult kestvana. Sillad teisenevad koos linnaga, kuid Kaplinski ei käsitle seda tervikprotsessi nii laial linnaelemente hõlmaval skaalal kui Kangro.

Üleujutuste stiihiaga kõrvutub peategelase mõtteis leekide võimsus, mida ta koges koolieas, kui „Riia mäel põles EPA peahoone katus” (Kaplinski 2007: 266; põleng toimus 10. veebruaril 1956). Nagu Benno saatja Hele-Mallgi, ei meenuta ka 
Kaplinski tegelane hoone varasemat funktsiooni - ja erinevalt Bennost ei pööra ta tähelepanu selle ees seisvale Leninile, olgugi et monument püstitati Riia mäele juba 1952. aastal (Raendi 1980: 15). Küllap on mängus soovimatus sellega suhestuda, sest muidu jagub tal küll tähelepanu mälestusmärkidele, nii et ta arvab end mäletavat „vist kõiki südalinna liivakaste ja mälestussambaid ” (Kaplinski 2007: 245). Sammastega on aga lugu nagu sildadegagi: kõik monumendid pole enam samad ja kõiki pole enam alles. Nii on juhtunud Amandus Adamsoni loodud ja Kalevipojaks kutsutud Vabadussõja mälestusmärgiga:

Ta oli siis vist teises klassis, see oli kevadel: nad jooksid vahetunnil jõe äärde ja nägid, kuidas traktor törtsudes tiris trossiga laiali postamendi suuri kivitahukaid. Kalevipoja süü oli selles, et ta oli püstitatud Vabadussõja sambana ja kandis seda Vabadussõja kahtlast vaimu ka pärast seda, kui aastaarvud 1918-1919 olid sambalt kustutatud. Nii pidi ta koos postamendiga kaduma ja mõni aeg hiljem ilmus tema asemele Kreutzwald. (Kaplinski 2007: 245)

Tamm ja Halla (2008) meenutavad, et 1920.-1930. aastatel kujunes piirkondlikke langenuid mälestavatest kohalikest algatustest üleriigiline Vabadussõja monumentide kampaania, mille raames püstitati ka Kalevipoeg. Kui Nõukogude Liit 1944. aastal Eesti taasvallutas, oli mõistagi vaja linnaruumi tähendusstruktuurid ümber korraldada ning Eestimaa Kommunistliku Partei juht Nikolai Karotamm käivitas vastassuunalise kampaania, andes 1945. aasta augustis käsu Vabadussõja monumendid kuu aja jooksul jäljetult kõrvaldada (Tamm, Halla 2008: 30), kuigi tegelikkuses jõuti selle ettevõtmisega enam-vähem lõpule alles 1950. aastate alguses. 1980. aastate lõpus järgnes vastupidine, restitutsiooniperiood, mil monumendipoliitika ülesandeks oli Eesti mälumaastikud oma märkide abil taas topograafiliselt üle kirjutada (Tamm, Halla 2008: 38).

Pärast Kalevipoja hävitamist 1950. aasta 28. aprillil võeti 11. mail maha Villem Reimani monument Toomel, mida Kaplinski peategelane samuti mäletab oma lapsepõlve linnamaastiku osana: „Villem Reiman, kellest ta lapsena teadis vaid nime, oli ka läinud, tema asemel oli vaid tühi koht” (Kaplinski 2007: 245). Veel üks meenuv mälestusmärk on Gustav Adolfi ausammas ülikooli taga, mis asendati betoonist lillevaasiga: „Tema mäletas kuninga kuju veel hästi: siit olid nad vanaisaga palju kordi mööda jalutanud ja muidugi oli vanaisa talle jutustanud Gustav Adolfist, tema tegudest ja surmasaamisest selsamal päeval, mille eel ta oli alla kirjutanud ülikooli asutamise ediktile" (Kaplinski 2007: 310).

Restitutsiooniajal kõrvaldatud nõukogude monumentide asukohtade kohtlemiseks on leitud kolm peamist lahendust: koht säilib monumendikohana, mis on valmis taaskasutuseks; monumendipaik kustutatakse, näiteks haljastuse abil; või jääb asukoht silmatorkavaks, kuid kujundatakse ümber seda „enda omaks” muutes, nagu on toimunud Riia mäe Lenini asupaigaga (Lillepõld 2014: 19). Praegu ei tõkesta see pääsu nüüdseks Balti Kaitsekolledžile kuuluvasse õppehoonesse, vaid toimib sellele suunduva väljakuna, mis „on saanud tagasi 1939. aastal algselt planeeritud tseremoniaalse tunde" (Lillepõld 2014: 18). Nõukogudeaegne likvideerimislaine, mille tun- 
nistajaks on Kaplinski, kustutas Reimani ja Gustav Adolfi ausamba asemed, samal ajal kui Vabadussõja mälestusmärgi asukohta taaskasutati: sinna paigutati metonüümiliselt seotud skulptuur, mis oli uuele režiimile vastuvõetavam. Praeguseks taas Kalevipojale koha vabastanud ja puiestikus edasi kolinud Kreutzwaldi kuju on ainus kultuuritegelase monument, mis Eestis Stalini ajal püstitati (Oselin 2004: 88), ning moodustab ideoloogiliselt kõige vähem agressiivse osa 1952. aastal aset leidnud monumendiofensiivist, mille skaala teises otsas seisis Lenin. Kokku rajati Tartus tol aastal neli monumenti, mainitutele lisandusid arstide Pirogovi ja Burdenko skulptuurid (Raendi 1980: 42, 45). Nendegi kujude kerkimist on Kaplinski tähele pannud ja kommenteerib irooniliselt:

Pääle Lauluisa oli ka teisi uusi sambaid - Pirogov ja Burdenko. Need sambad pidid tähistama eesti ja vene rahva ajaloolist sõprust, olema ülikoolilinna tänuavaldus suure naaberrahva suurtele poegadele, kes on siin töötanud ja linnale kasu ning kuulsust toonud. (Kaplinski 2007: 246)

Katsena manipuleerida kollektiivse mäluga ei olnud monumentide likvideerimis- ja püstituslained kuigi subtiilsed ettevõtmised, kuid kunstiliselt teostuselt edestasid uued skulptuurid tsemendist ja kipsist masstoodangut, mis kuni laiali pudenemiseni tähistas Nõukogude avalikke ruume - sellistest möödub Kaplinski tegelane jalgrattal, kui vana postiteed mööda maale sõidab: „Uute aegade märgiks olid vaid kraavide äärde istutatud õunapuud ja kased ning paar kipskuju - ühes kohas pioneer pasunaga, teises murtud sarvega hirv" (Kaplinski 2007: 115). ${ }^{2}$ Ehkki ajastu ei lubanud esile tulla kunstnike isikupäral, tagasid eesti skulptorite loodud graniitpostamentidel pronkskujud, mis samas vältisid stalinistlikku suurustamist, kõigele vaatamata teatava esteetilise tulemuse (Oselin 2004: 89, 118). Neist ainsana oma algses asukohas püsiv Pirogov on praeguseks kujunenud suisa uue tähendusväljaga maamärgiks, sümboliseerides totalitaarse süsteemi haarde ja lahinguväljaeetri asemel reeglite lokaalset paindlikkust ning vabaõhualkoholi.

Lisaks linnas aset leidnud mälupidemeteisendustele monumendikampaaniate käigus täheldab Kaplinski peategelane ka ühe märgilisema nõukogude institutsiooni, julgeoleku ruumilist teisenemist: „Tema lapsepõlve aegu oli julgeoleku maja olnud teises kohas - Riia tänava ristil. Seda kutsuti Halliks Majaks ja temast räägiti kartlikul sosinal. Enamasti õudusjutte peksmistest ja piinamistest ja inimestest, kes säält enam tagasi ei tulnudki - kadusid nagu tina tuhka." (Kaplinski 2007: 237) Saatuse iroonia tahtel oli selle kurja kuulsusega hoone arhitekt Arnold Matteus, kellelt Tartu ärimees Oskar Sõmermaa oli 1935. aastal projekti tellinud. Maja valmis 1938, kuid Nõukogude okupatsiooni ajal see natsionaliseeriti ning sellest sai NKVD kohaliku osakonna peakorter (Kuusk 2006). 1954. aastal omandas KGB-ks ümber nimetatud organisatsioon XIX sajandist pärineva Berliini villastiili mõjudega neorenessansshoone Vanemuise tänaval, mis sõja eel oli kuulunud Eesti Kirjanduse Seltsile ja

\footnotetext{
${ }^{2}$ Hirvele annab romaanis „Kivisild” esteetilise hinnangu ka Benno: „Ja kui Ihamaru lähedal toda vana kivi näed, mille otsa oli mõni aeg tagasi suur inetu põdrakuju pandud, jälle endisena, puhtana, tahad peatuda ja ise seal istuda ja laulda nagu vanasti” (Kangro 1963: 114).
} 
Eesti Kirjanikkude Liidule. Mingeid kirjanduslikke seoseid Kaplinski raamatus selle majaga ei teki, peategelane pole neid ise kogenud ning näib, et ka vastav pärimus pole tema jaoks aktuaalne olnud:

Pärast Stalini surma ja Beria kukutamist oli julgeolek muutnud oma nime ja nägu. Temast ei teatud enam kuigi palju, ja kui räägiti, siis ilma selle õuduseta, mis oli varjutanud kõike Halli Majaga seotut. Uus, väiksem ja tähelepandamatum julgeolek oli kolinud väiksemasse majja, millest ta sageli mööda käis. See olla olnud kellegi mõisniku maja, välisukse ees kõrge trepp, akende all mururiba, kus kasvas sirelipõõsas ja kõrge pihlakas ja seisis betoonist vaas lilledega. (Kaplinski 2007: 237)

Need eri perioodidest pärinevate ja muutunud rollis kurikuulsa aura omandanud linnamajade pildid on ühtlasi kõige üksikasjalisemad ülevaated hoonetest Kaplinski tekstis, illustreerides kujukalt Stuart Burchi ja David Smithi (2007: 917-918) arutelu sellest, kuidas poliitilised muutused suudavad muuta mälestiste tähendust, ilma et need füüsiliselt teiseneksid. Funktsionalistliku või historitsistliku ehituskeskkonna tähenduste alistumine sinna sisse kolinud ideoloogiliste võimustruktuuride omale laseb valitseval ideoloogilisel kultuuritekstil tõepoolest varjata linnapalimpsesti marginaalseid lõimi, kuigi viimased on ehitistena vaatamiseks väljas ning esimene eelistab tegutseda varjatult.

\section{Linnapalimpsesti ruumiretoorikast}

Kangro Benno võis Halli Maja kuulsusest olla niisama teadlik kui tema autorgi: 1941. aastal üllatas NKVD Kangrot ka tema kodus, kuid kirjanikul õnnestus tagauksest põgeneda (Kruus 2003: 38) ja järgmine Tartu-tsükli romaan „Kivisild” teatab otse: „Teati küll, et see asutus on enda alla võtnud endise Zimmermanni maja” (Kangro 1963: 239). KGB hoonet Vanemuise tänaval Benno oma külaskäigul siiski ei näe ja tema pildilt puudub ka teine oluline nõukogude võimutähis, Raadi lennuväli. Inglisillalt heiastub Raadi suunal vaid hõllanduslik kevadmaastik: „Kuid endine on ikkagi haljas Emajõe luht ja selle keskel vilgatav jõgi, punane liivakivipaljand üle jõe surnuaia all ja silmapiiril laiuv maa. Õrn-õrn sinkjas vine on üle kauge maastiku, taevarannal uneleb rodu valgeid pilvi nagu utevilla tätraid." (Kangro 1996: 206) Kaplinski peategelasel on seevastu raske Toomemäel käia, ilma et ta teadvustaks kaugusest paistvaid lennukeid (Kaplinski 2007: 109, 236, 245), rääkimata nende tekitatud mürast ning hirmuäratavatest madallendudest (Kaplinski 2007: 245). Lennuvälja olemasolu ei piira üksnes linna laienemist, vaid kammitseb ka tsiviilelanike võimalusi: „Nad kõndisid veel natuke, seisid künkal Vallikraavi tänava kohal, kust olid näha kaugel eemal seisvate lennukite sabad. Lennukite sabad, kelle pärast välismaalasi kuidagi Tartusse ei tahetud lasta, kelle pärast nemad, inglise või prantsuse keele õppijad, ei kohtunud terve ülikooli aja ühegi inglase või prantslasega." (Kaplinski 2007: 236) Just lennuväli võimaldab Bennol käia Tartus üksnes kummitusena, kuid sellega seonduv puudub tema vaateväljast samavõrra kui nõukogude kaartidelt. 
Certeau (2005: 158) käsituses on valikulisus ja väljajättelisus omane kõndimisele kui lausumise ruumile, mis annab „mõnele ruumielemendile eesõiguse, teisendab neid või jätab unarusse"; kõndimisvalikute tõttu võib mõni koht sootuks haihtuda või ilmneda haruldase või suisa lubamatu ruumilise „väljendina” (Certeau 2005: 159). Certeau (2005: 161-162) kõrvutab selliste ruumipraktikate struktuuri sünekdohhi ning asündetoni stiilivõtetega. Kangro linnakujutust iseloomustab pigem asündeton: Benno linnakogemus on Kangro esituses katkendlik ja selektiivne, autor teeb kärpeid ja väljajätteid, tunnistab puudu olevat oma linnapildis. Kui Kangro kirjeldab Bennot meenutamas kahjustatud või kadunud hooneid ning trotsimas ruumi anastamist uute nimede kaudu, on tema Tartus teineteise peal esitatud kaks diskreetset, teineteisest eraldatud linnastaadiumi. Kaplinski tegelase jalutuskäike iseloomustab aga pigem sünekdohh: neis keskendutakse valitud elementidele, mille üksikasju tihendatakse ja võimendatakse, nii et need jäävadki esindama kogu linnatervikut. Jälgides valikulisi protsesse, näiteks mälestusmärkide kohtlemist, toob ta esile mälu modifitseerimise pidevuse; isiklikest kodustest ruumidest otsib ta vargsi esile immitsevaid ideoloogiliselt tõrksaid minevikke ja nende nostalgilist rahuaurat.

Kumbki kõndija viib linnaruumi sisse „hulganisti omaenda osutusi ja tsitaate” (Certeau 2005: 161), ent mõlemad teosed suunavad tegelast suhestuma linnapalimpsestiga vastupanuna avalikus ruumis materialiseerunud ametlikule mäludiskursile nende ruumipraktikad „,õimaldavad neil avaldada linnaruumis vastupanu ülevaltalla suunatud strateegiatele", nagu Jussi Jauhiainen (2005: 71) võtab kokku Certeau linnakäsitluse. Koht on Certeau (2005: 272) järgi „mitte-nüüdisaegsetest, kuid hävinenud tervikutega ikka veel seotud tükkidest" koosnev kogum ja seesugusena võib kirjeldada ka vaadeldavates teostes kirja pandud Tartu linna. Näiliselt kustutatud materjali „lugedes” suhestuvad Kangro ja Kaplinski tegelased linnaruumis kõndides Tartu fragmentaarse minevikuga, pööramata samal ajal tähelepanu võimalikele laiahaardelistele tulevikustsenaariumidele, mida võiks tuletada sõjajärgsest ülesehitusprogrammist.

Vaatamata ajaloolistele mahakustutustele ning ideoloogilistele ümbertõlgendamispüüetele võimaldab palimpsestlik linnaruum ligipääsu ebatäiuslikult kustutatud minevikukihtidele, eriti sõjaeelsele Eesti Vabariigile. Kaplinski reaalsuse linn on tugevamini läbi põimunud Nõukogude võimustruktuuride ruumilise kohaloluga kui Kangro kujutluste pealinn, kuid Kangro Benno nostalgilised mälestused langevad kokku Kaplinski tegelase eskapistlike Tartu-unelmatega. Certeau mõttekäikudes on need poolused teineteisest nii ehk teisiti vastastikku sõltuvad, sest: „Mäletatav on see, mida kohast saab ette kujutada" (Certeau 2005: 171). Vaatamata sellele, et mõlemad lood lähenevad 1960. aastate linnale eri suundadest ja eri moel, jõuavad nad ühte ja samasse ebatõelisse linna: näiliselt kadunud 1930. aastate Tartusse, mida siiski pole täielikult kustutatud ja mida Kangro Benno püüab palimpsestlike kihtide põhjal taastada ning Kaplinski peategelane välja mõelda. 
Artikli ilmumist on toetanud Eesti Teadusagentuuri personaalse uurimistoetuse rühmagrant PRG314 "Semiootiline sobivus kui biokultuurilise diversiteedi mehhanism: ebastabiilsus ja kestlikkus uutes keskkondades". Tänan Kirjanduslike Linnauuringute Assotsiatsiooni (Association for Literary Urban Studies) ja Jason Finchi artikli kirjutamiseks tõuke andmise eest ning tagasiside eest esialgsele versioonile.

\section{KIRJANDUS}

Annus, Epp 2019. Sotskolonialism Eesti NSV-s. Võim, kultuur, argielu. (Heuremata: humanitaarteaduslikke monograafiaid.) Tallinn-Tartu: Tartu Ülikooli Kirjastus.

Assmann, Aleida 1999. Erinnerungsräume. Formen und Wandlungen des kulturellen Gedächtnisses. München: C. H. Beck.

Bulgarin, Faddei 2019. Kirjad Karlova mõisast. Tlk Malle Salupere. Tartu: Ilmamaa.

Burch, Stuart; Smith, David J. 2007. Empty spaces and the value of symbols: Estonia's 'War of Monuments' from another angle. - Europe-Asia Studies, kd 59, nr 6, lk 913-936.

Certeau, Michel de 2005. Igapäevased praktikad I. Tegemiskunstid. Tlk Mirjam Lepikult. Tartu: Tartu Ülikooli Kirjastus.

Crang, Michael 1998. Cultural Geography. London-New York: Routledge.

Cunningham, Valentine 2002. Zerbombte Städte - Die vorzeitigen Ruinen des Zweiten Weltkriegs. - Ruinenbilder. Toim Aleida Assmann, Monika Gomille, Gabriele Rippl. München: Wilhelm Fink Verlag, lk 105-130.

Dillon, Sarah 2005. Reinscribing De Quincey's palimpsest: The significance of the palimpsest in contemporary literary and cultural studies. - Textual Practice, kd 19, nr 3, lk 243-263.

Hollo, Maarja 2016. Romantiline subjekt, mälu ja trauma Bernard Kangro sõjajärgses loomingus. (Dissertationes litterarum et contemplationis comparativae Universitatis Tartuensis 14.) Tartu: Tartu Ülikooli Kirjastus.

Huyssen, Andreas 2003. Present Pasts: Urban Palimpsests and the Politics of Memory. Stanford: Stanford UP.

Jauhiainen, Jussi S. 2005. Linnageograafia. Linnad ja linnauurimus modernismist postmodernismini. Tallinn: Eesti Kunstiakadeemia.

Kangro, Bernard 1963. Kivisild. Lund: Eesti Kirjanike Kooperatiiv.

Kangro, Bernard 1996. Tartu. Tallinn: Eesti Raamat.

Kaplinski, Jaan 2007. Seesama jõgi. Tallinn: Vagabund.

Kivi, Raul-Levroit 2017. Arhitekt kui dirigent. Artikleid, projekte, mälestusi. Tartu: Tartu Linnamuuseum.

Kruus, Oskar 2003. Bernard Kangro. Elukäik ja looming. Tallinn: Eesti Raamat.

Kuusk, Pearu 2006. KGB kongide muuseum Tartus. - Estonian World Review 9. VI. https:// www.eesti.ca/kgb-kongide-muuseum-tartus/article13475

Lagerkvist, Amanda 2011. Velvet and violence: Performing the mediatized memory of Shanghai's futurity. - Transversing Transnationalism: The Horizons of Literary and Cultural Studies. Toim Pier Paolo Frassinelli, Ronit Frenkel, David Watson. AmsterdamNew York: Rodopi, lk 33-55.

Laur, Mati 2005. Vene võimu all 18. sajandil. - Tartu: Ajalugu ja kultuurilugu. Koost Heivi Pullerits, toim H. Pullerits, Urmas Tõnisson, Allan Liim, Andres Andresen. Tartu: Tartu Linnamuuseum, Ilmamaa, $1 \mathrm{k}$ 57-65. 
Levinson, Sanford 1998. Written in Stone: Public Monuments in Changing Societies. Durham-London: Duke University Press.

Lillepõld, Raina 2014. Tühiku tõlgendamine: postsotsialistlik linnaplaneerimine pärast monumentide eemaldamist. - U, nr 16, lk 18-19.

Lotman, Juri; Uspenski, Boriss 1999. Müüt - nimi - kultuur. - J. Lotman, Semiosfäärist. Tlk Kajar Pruul. Tallinn: Vagabund, lk 187-210.

Marksoo, Ann 2005. Linnasiire. - Tartu: Ajalugu ja kultuurilugu. Koost Heivi Pullerits, toim H. Pullerits, Urmas Tõnisson, Allan Liim, Andres Andresen. Tartu: Tartu Linnamuuseum, Ilmamaa, lk 137-157.

Matteus, A[rnold]; Seero, M. 1960. Ehitustegevus. - 20 aastat Nõukogude Tartut. Majandusja kultuurielu lühike ülevaade. Toim Raimund Hagelberg. Tartu: Tartu Linna TSN Täitevkomitee Plaanikomisjon, lk 24-31.

Oselin, Tiina 2004. Eesti skulptorid ja nende looming 1950. aastate II poolel ja 1960. aastate I poolel. Ideoloogia ja mehhanismid. Magistritöö. Tartu Ülikool.

Pajur, Ago 2005. 20. sajand. - Tartu: Ajalugu ja kultuurilugu. Koost Heivi Pullerits, toim H. Pullerits, Urmas Tõnisson, Allan Liim, Andres Andresen. Tartu: Tartu Linnamuuseum, Ilmamaa, lk 73-97.

Plesske, Nora 2014. The Intelligible Metropolis: Urban Mentality in Contemporary London Novels. Bielefelt: transcript Verlag.

Preem, Marti 1996. Tartu ajaloolisest taustast tulenevaid arenguaspekte. - Postimees 23. I.

Raendi, Aili 1980. Tartu ajaloo- ja kultuurimälestised. Tallinn: Eesti Raamat.

Salumets, Thomas 2016. Kujuneda sunnita: mõtestades Jaan Kaplinskit. Tlk Kersti Unt. Tallinn: Varrak.

Salupere, Malle 2011. Tuhandeaastane Tartu: nooruse ja heade mõtete linn. Teine, täiendatud trükk. Tartu: Vanemuise Seltsi Kirjastus.

Siilivask, Karl 1960. Nõukogude võimu taaskehtestamine 1940. aastal ja sotsialistliku ülesehitustöö algus. - 20 aastat Nõukogude Tartut. Majandus- ja kultuurielu lühike ülevaade. Toim Raimund Hagelberg. Tartu: Tartu Linna TSN Täitevkomitee Plaanikomisjon, lk 5-10.

Siilivask, Mart 2006. Tartu arhitektuur 1830-1918. Historitsism ja juugend. Tartu: Rahvusarhiiv.

Soovik, Ene-Reet 2019. Rebenenud linn. II maailmasõja linnamaastikud Bernard Kangro Tartu-tsükli kolmes viimases romaanis. - Methis, kd 19, nr 24, lk 59-84.

Tamm, Marek; Halla, Saale 2008. Ajalugu, poliitika ja identiteet. Eesti monumentaalsest mälumaastikust. - Monumentaalne konflikt. Mälu, poliitika ja identiteet tänapäeva Eestis. Toim Pille Petersoo, M. Tamm. Tallinn: Varrak, lk 18-50.

Tohvri, Epi 2004. Ehitusmeistrist arhitektiks: G. F. W. Geist Tartu linnaruumi kujundajana 19. sajandi esimesel poolel. - Kunstiteaduslikke Uurimusi / Studies on Art and Architecture, kd 13, nr 3-4, lk 50-74.

Uricchio, William 2012. A palimpsest of place and past. - Performance Research, kd 17, nr 3, lk 45-49.

Vanemuine 2017 = Vanemuise suur maja - 50! https://www.vanemuine.ee/uudista/vanemuise-suur-maja-50/ (15. IX 2020). 
Velsker, Mart; Soovik, Ene-Reet 2017. Cities within a second city: The case of literary Tartu. - Literary Second Cities. Toim Jason Finch, Lieven Ameel, Markku Salmela. Cham: Palgrave Macmillan, lk 89-108.

Ene-Reet Soovik (snd 1968), MA, Tartu Ülikooli filosoofia ja semiootika instituut, semiootikaajakirja Sign Systems Studies toimetaja (Jakobi 2, 51014 Tartu), ene-reet.soovik@ut.ee

\section{In search of a lost city: The palimpsest of post-war Tartu in Bernard Kangro's and Jaan Kaplinski's novels}

Keywords: urban literature, palimpsest, bridges, monuments, Tartu, Bernard Kangro, Jaan Kaplinski, Michel de Certeau

The article focuses on two literary depictions of the city of Tartu as examples of palimpsestic treatment of a city space recovering from major damage incurred in WWII and reshaping itself in the changed political climate of the ensuing Soviet occupation. The novels Tartu (1962) by Bernard Kangro and The Same River (2007) by Jaan Kaplinski feature the same cityscape from around 1960 that the authors have been unable to access directly during the time of writing. The distance is spatial in case of Kangro, whose novel was created in exile, and temporal in case of Kaplinski, whose work was written in the independent Estonia of the $21^{\text {st }}$ century.

The texts are discussed, drawing on the notion of the materiality of memory as well as Michel de Certeau's ideas concerning the spatial practices of walking in the city. The evocation and mental reviving of surviving as well as vanished structures at the expense of new developments, and highlighting space appropriation by naming stand out among the devices operating in Kangro's novel. Reflecting on attempts at memory modification through demolishing and erecting public monuments, and searching for ideologically unsuitable pasts in private places are predominant in representing the city palimpsest in Kaplinski's work.

Using a typology suggested by Certeau, Kangro's depiction can be characterised by the selective figure of the asyndeton that operates via deletion from the city representation of new developments and Soviet institutions such as the military airfield and the KGB. Kaplinski's text, however, zooms in on certain elements, such as monuments serving as public and private memory triggers, and expands their significance, thus serving as Certeau's figure of the synecdoche. Despite approaching it from different directions, both writers reach out for the same unreal city: the superficially lost, yet imperfectly erased Tartu of the 1930s.

Ene-Reet Soovik (b. 1968), MA, University of Tartu, Institute of Philosophy and Semiotics, editor of the semiotics journal Sign Systems Studies (Jakobi 2, 51014 Tartu), ene-reet.soovik@ut.ee 